\title{
Morphometry and Histochemistry of the Rectus abdominis Muscle Fibers of Tufted Capuchin Monkeys (Cebus apella Linnaeus, 1758).
}

\author{
Morfometría e Histoquímica de las Fibras del Músculo Recto del Abdomen \\ del Mono Capuchino Almohadillado (Cebus apella Linnaeus, 1758). \\ "L. H. Simionato; "J. C. Andreo; ** J. A. de Oliveira; "C. H. F. Bortoluci; \\ ${ }^{* * *}$ N. B. dos Santos; "L. H. R. Moraes; ${ }^{* * *}$ A. C. Rodrigues \& "M. B. Andreo
}

SIMIONATO, L. H.; ANDREO, J. C.; OLIVEIRA, J. A.; BORTOLUCI, C. H. F.; DOS SANTOS, N. B.; MORAES, L. H. R.; RODRIGUES, A. C. \& ANDREO, M. B. Morphometry and histochemistry of the Rectus abdominis muscle fibers of tufted capuchin monkeys (Cebus apella Linnaeus, 1758). Int. J. Morphol., 24(1):53-60, 2006.

SUMMARY: The phylogenetic proximity of primates to humans, along with their behavioral, biochemical, and anatomical similarities, make such animals more interesting experimental models for biomedical researches, as compared to classical laboratory animals. Another aspect that has called the attention of researchers is the differentiated quadrupedalism present in some primates. The tufted capuchin monkey uses the ground and tree branches as its support for locomotion, showing various postures while performing this task. On the basis of this information, we have decided to study the rectus abdominis muscle of the tufted capuchin monkey, with the following goals: the frequency and area of fiber types; its possible compartmentalization; and identify if this muscle is better adapted to phasic or postural activities. To do this, samples were removed from 4 regions of the rectus abdominis muscle of 6 adult male tufted capuchin monkeys, and were submitted to reaction with m-ATPase, (with alkaline and acid pre-incubation), NADH, and H.E.. Results showed: a statistically significant difference $(\mathrm{P}<0.05)$ for both frequency and area, between fiber types FG and FOG and FG and SO, but did not show a statistically significant difference between fibers FOG and SO, in all studied regions; similarity in frequency and area of a same fiber type (FG, FOG, and SO) among the studied regions. Based on these data, it was concluded that: the rectus abdominis muscle of the tufted capuchin monkey does not show fiber compartmentalization, since the distribution and size patterns of the different fiber types are similar in the studied regions; there is a predominance of fast twitch fibers (FG + FOG) over slow twitch fibers (SO), for frequency and area, which characterizes the muscle as being more dedicated to phasic than to postural activities.

KEY WORDS: Rectus abdominis muscle; Histochemistry; Musculars fiber types; Tufted capuchin monkey; Cebus apella; Primates; Simians.

\section{INTRODUCTION}

Due to phylogenetic proximity, added to the biochemical, physiological, anatomical, and behavioral similarities to man, non-human primates have been considered to be more appropriate experimental models for biomedical researches, thus being preferred over other laboratory-bred mammals Cooper (1968). Another aspect that has attracted researchers' interest is the differentiated quadrupedalism that some of these animals possess.

In biomedical researches with primates, New World monkeys have lately attracted great interest, mainly Cebus apella, popularly known as tufted capuchin monkey, due to the aforementioned aspects, besides the low cost for breeding, and less handling difficulties, when compared to the large Old World simians Szabuniewicz et al. (1971).

It can be affirmed that every animal's musculature is projected to perform important functions, adapting to the animal's needs for survival. Therefore most researches are emphasized on the relation of muscular morphology with

\footnotetext{
* Sacrad Heart University/USC, Brazil.

** São Paulo State University "Julio de Mesquita Filho"/UNESP - Araçatuba, Brazil.

**** Bauru Dental School, University of São Paulo, Brazil.
} 
the behaviors to which the animal's well-being depend on. For instance, fast ways of locomotion are considered to be of greater importance that those of a casual stroll, since the former can be a mechanism to flee from danger. If special postures for feeding are used, they are more highly considered than special rest postures, in that they may allow the organism to obtain food that would otherwise be inaccessible, Stern (1971).

According to Stern, the first task to determine the correlation between an animal's structure and its way of locomotion is to discover how the investigated animal actually moves.

Some primates live in a terrestrial and arboreal habitat, and have a diversity of movements for locomotion. In this case, the abdominal muscles take part in the control of movements that are performed when climbing, jumping, walking, and running. The muscles of the abdominal wall take part in many movements including those of the trunk and the pelvis, contributing to flexion, rotation, and dissociation of the trunk and pelvis, which helps locomotion.

Although abdominal muscles participate in such important movements, literature shows only few works on this subject, in comparison to the data found on limb musculature.

The type of activity performed by a muscle is usually revealed by the histochemical profile of its fiber types. When a muscled is involved in fast movement, there is a predominance of fiber types FG and FOG; whereas an antigravitational muscle, involved in the maintenance of a static posture, will show a predominance of SO fibers. Therefore, the composition of a skeletal muscle's fiber types may vary among species, according to their posture, and within the same animal among its muscles, depending on the type of activity performed Ariano et al. (1973); Armstrong et al. (1982).

The use of histochemical and morphometric techniques has shown satisfactory results for the identification of a muscle fibers' histochemical types, besides its alterations, when this occurs for some reason, such as with the administration of a certain drug, or submission to a certain treatment.

Taking this into consideration, it was decided to perform this study with the purpose of observing, in the rectus abdominis muscle of the tufted capuchin monkey: the frequency and area of the different fiber types in its various regions; if this muscles shows compartimentalization or not; and if this muscle is better adapted for tonic of phasic activities.

\section{MATERIAL AND METHOD}

Six adult male tufted capuchin monkeys (Cebus apella, Linnaeus, 1758) were used. The animals were obtained by the Tufted Capuchin Monkey Procreation Nucleus of the Dental School of the Araçatuba Campus, UNESP.

The animals were kept under fasting conditions, with access to water, for the 12 twelve hours before surgery. Animals were intraperitoneally anesthetized with sodic Thiopental, at a dosage of $30 \mathrm{mg} / \mathrm{kg}$ body weight. Next, four samples of the rectus abdominis muscle were obtained from the right side of each animal, always in the central region of each belly, this way avoiding the tendinous areas, as proposed by Costerbosa et al. (1988). The samples were identified as proximal (P), middle proximal (MP), middle distal (MD), and distal (D).

The samples were covered with neutral talcum and frozen in liquid nitrogen by the method of Werneck (1981). The samples were then kept in a container containing liquid nitrogen, until the moment of being submitted to histochemical reactions.

A number of sections of $12 \mu \mathrm{m}$ in thickness were obtained from the muscular samples, which were submitted to the following staining and reactions: HE, following the method of Behmer et al. (1976); m-ATPase with alkaline (pH 10.4) and acid (pHs 4.55 and 4.35) pre-incubations following Padykula and Herman (1955), modified by Dubowitz \& Brooke (1973); and NADH-Tr according to the method of Pearse (1968), modified by Dubowitz \& Brooke.

Equal microscopic fields were selected from the sections that had been submitted to m-ATPase and NADHTR reactions, and were used for muscle fiber classification. The fibers were classified according to Peter et al. (1972).

Frequency and area of the different muscle fiber types were calculated with the aid of an image analysis system, model Image-Pro, version 4.1, coupled to a computer. The obtained data were submitted to multivariate analysis of variance involving the mean profiles of responses complemented with the respective simultaneous confidence intervals, with a 5\% level of significance ( $\mathrm{P}>0.05)$; Johnson \& Wichern (1998).

\section{RESULTS}

The samples obtained from the different portions of the rectus abdmominis muscle of the tufted capuchin monkey and submitted to reaction with m-ATPase with pre-incubations in $\mathrm{pHs}$ 10.4, 4.55, and 4.35, and NADH-Tr showed similar results; which are listed in Table I and illustrated in Figs. 1, 2, 3, and 4, respectively. 
The distribution of frequency and area of the different fiber types found in the different regions of the rectus abdominis muscle of the tufted capuchin monkey are shown in Tables 2 and 3, respectively.
Means followed by different letters are statistically different among them by Tukey test at $5 \%$ probability. Small letters (vertical) - comparison of each fiber type among the studied regions. Capital letters (horizontal) - comparison between fiber types within each studied region.

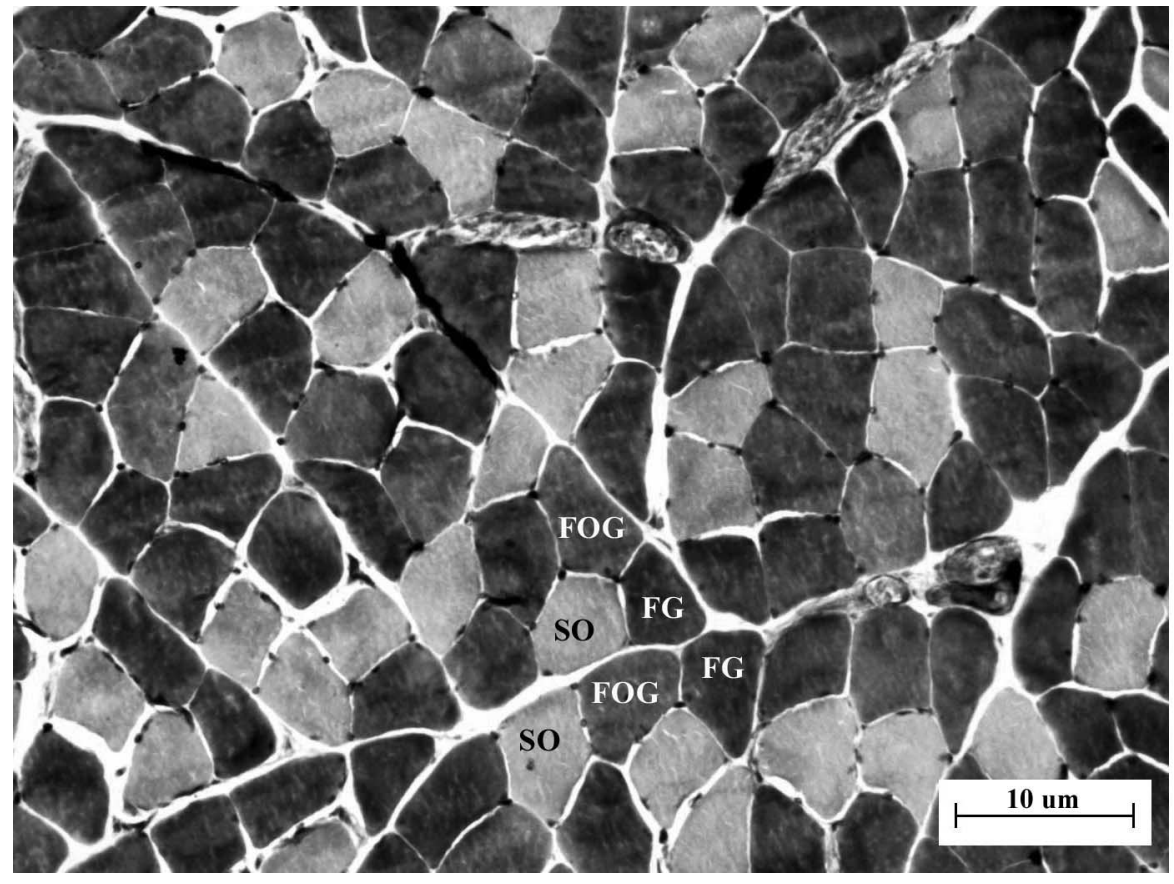

Fig. 1. Rectus abdominis muscle of the tufted capuchin monkey submitted to mATPase reaction with alkaline pre-incubation $(\mathrm{pH} 10.4$ )

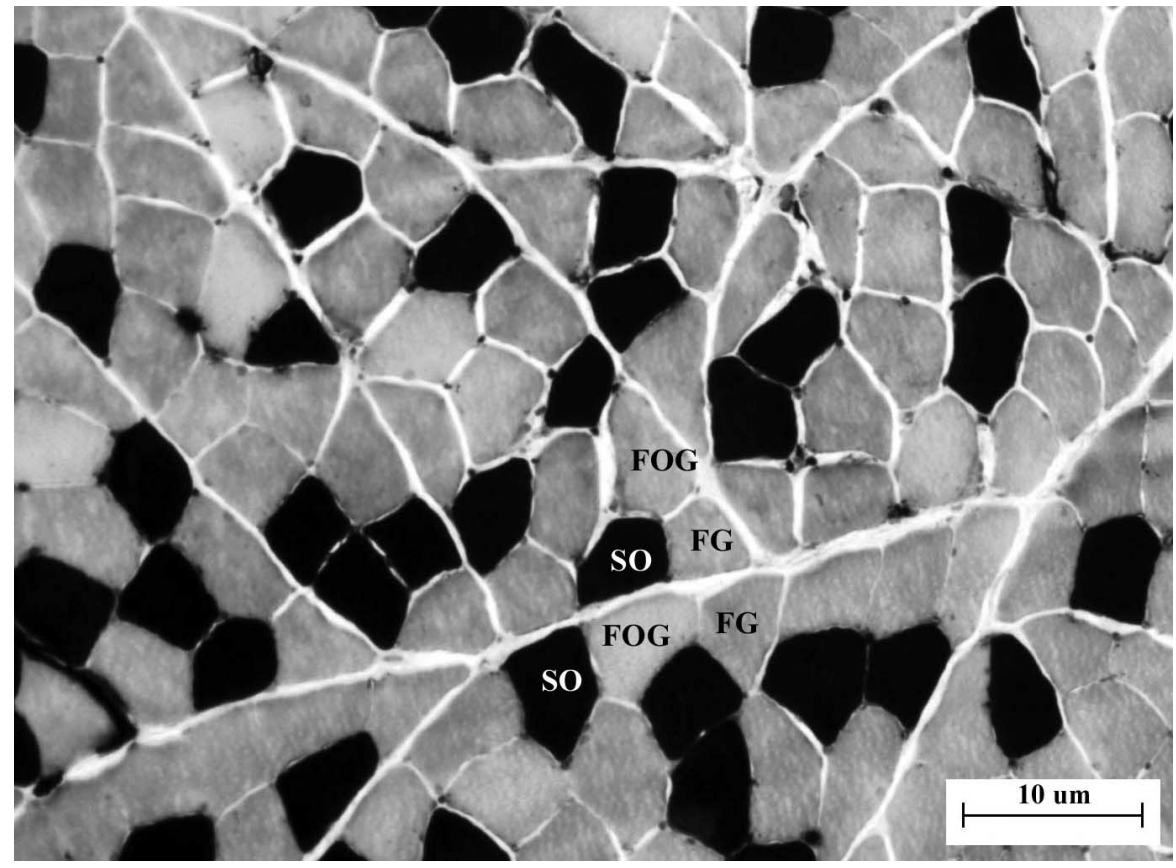

Fig. 2. Rectus abdominis muscle of the tufted capuchin monkey submitted to mATPase reaction with acid pre-incubation ( $\mathrm{pH} 4.55)$
With basis on the data from Table II, it can be seen that the frequency of each fiber type is similar for all studied locations, as ANOVA did not show any statistically significant difference among them. A similarity can also be observed when the different fiber types are compared in each studied region, in which FG type was always the most frequent, including that it shows a statistically significant difference with the other types, whereas no statistically significant difference was found between the types FOG and SO.

Means followed by different letters are statistically different among them by Tukey test at $5 \%$ probability. Small letters (vertical) - comparison of each fiber type among the studied regions. Capital letters (horizontal) - comparison between fiber types within each studied region.

With basis on the data from Tabel III, it can be observed that: the area of each fiber type was similar in the different studied regions; although the area of FG fibers increases in a proximal to distal direction, the differences were not statistically significant; when the area of the different fiber types is observed, within each studied region, a similar pattern can also be notices, in which the areas of FG fibers are always greater, including that it shows statistically significant differences with the others; the area of FOG fibers is always greater than that of SO fibers, despite the difference being statistically significant only in the proximal region. 
Table I. Results of the histochemical m-ATPase (with alkaline and acid pre-incubations) and NADH-Tr reactions of the rectus abdominis muscle of the tufted capuchin monkey (Cebus apella).

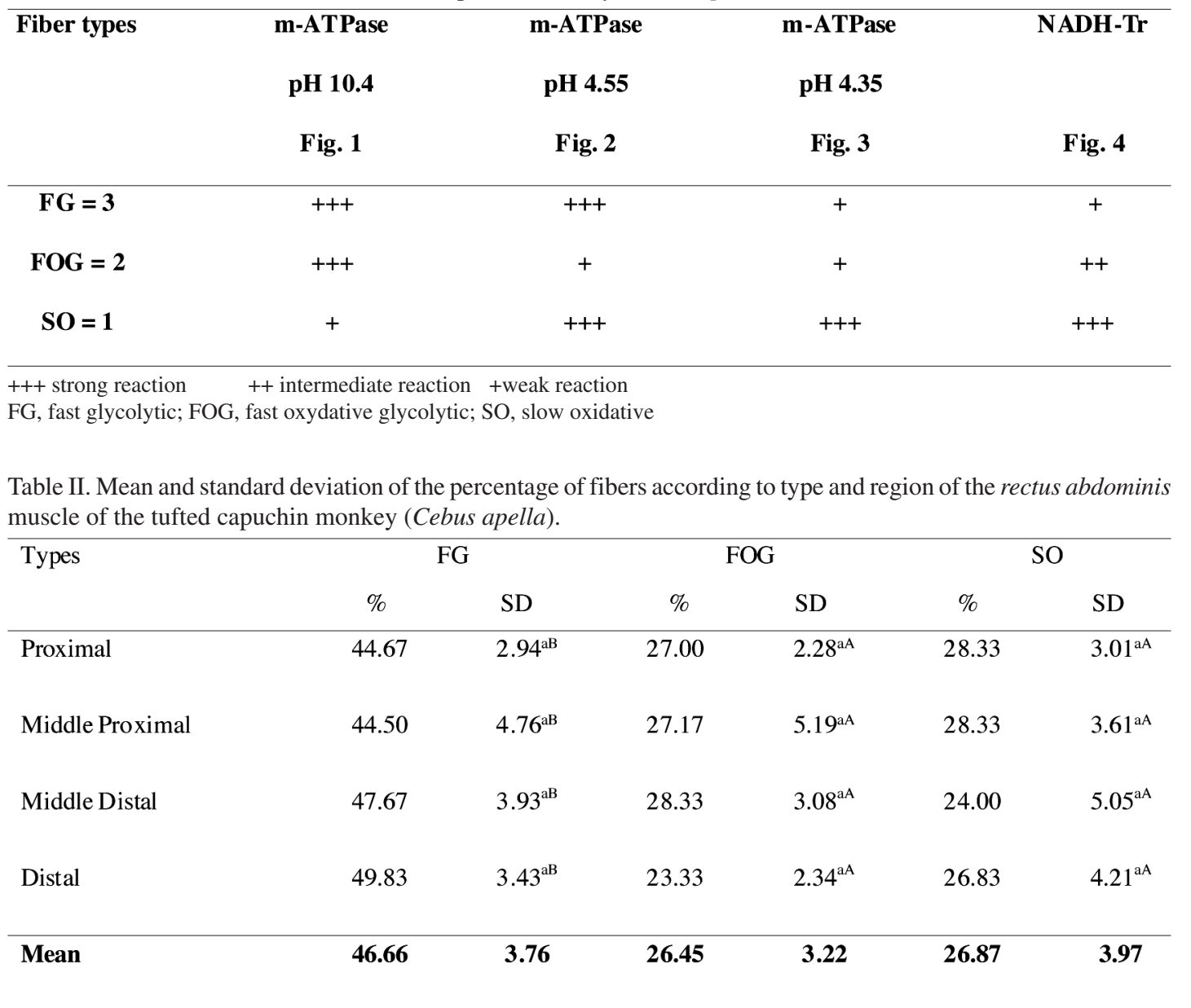

FG, fast glycolytic; FOG, fast oxydative glycolytic; SO, slow oxidative

Table III. Mean $\left(\mu \mathrm{m}^{2}\right)$ and standard deviation of fiber area in terms of type and region of the rectus abdominis muscle of the tufted capuchin monkey (Cebus apella).

\begin{tabular}{|c|c|c|c|c|c|c|}
\hline \multirow{2}{*}{ Types } & \multicolumn{2}{|c|}{ FG } & \multicolumn{2}{|c|}{ FOG } & \multicolumn{2}{|c|}{ SO } \\
\hline & $\mathrm{X}$ & SD & $\mathrm{X}$ & SD & $X$ & SD \\
\hline Proximal & 8.28 & $1.54^{\mathrm{aC}}$ & 5.24 & $0.56^{\mathrm{aB}}$ & 3.89 & $0.99^{\mathrm{aA}}$ \\
\hline Middle Proximal & 9.02 & $3.22^{\mathrm{aB}}$ & 4.96 & $0.58^{\mathrm{aA}}$ & 3.81 & $0.54^{\mathrm{aA}}$ \\
\hline Middle Distal & 10.26 & $2.43^{\mathrm{aB}}$ & 5.61 & $1.34^{\mathrm{aA}}$ & 5.05 & $0.75^{\mathrm{aA}}$ \\
\hline Distal & 11.94 & $2.59^{\mathrm{aB}}$ & 5.05 & $0.75^{\mathrm{aA}}$ & 4.21 & $1.04^{\mathrm{aA}}$ \\
\hline Mean & 9.87 & 2.44 & 5.21 & 0.80 & 4.24 & 0.83 \\
\hline
\end{tabular}

FG, fast glycolytic; FOG, fast oxydative glycolytic; SO, slow oxidative 


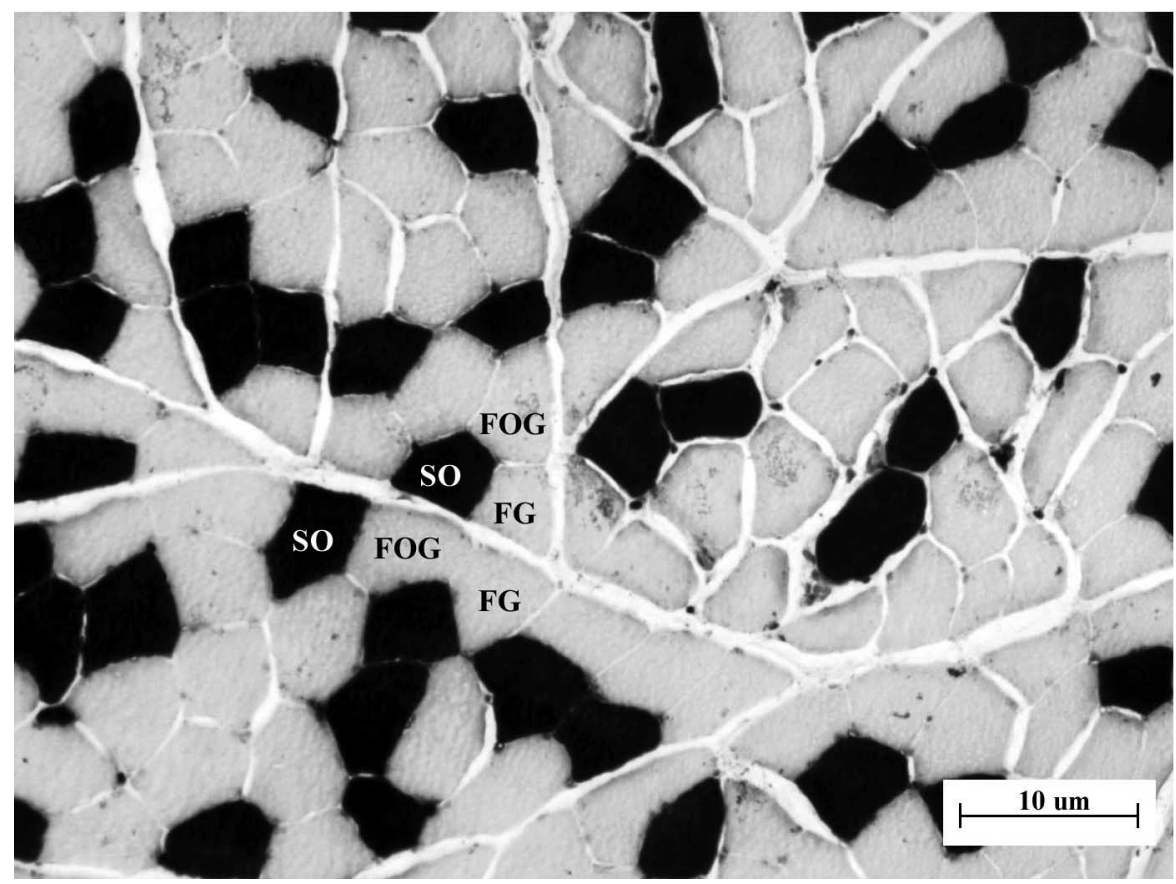

Fig. 3. Rectus abdominis muscle of the tufted capuchin monkey submitted to m-ATPase reaction with acid pre-incubation ( $\mathrm{pH} 4.35)$

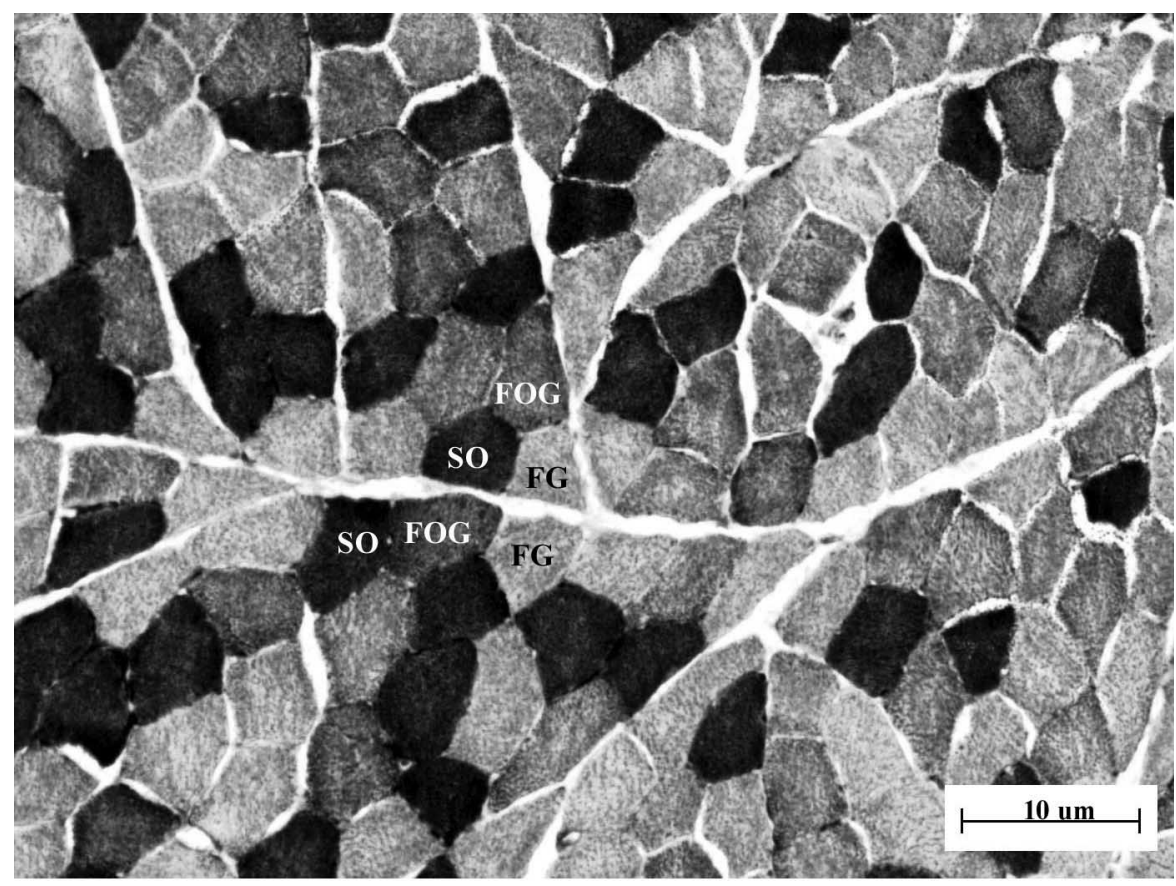

research with that of other animals rather difficult.

Studies with histochemical classification of muscle fibers show various denominations for these fibers; in this work the Myrhage (1977) correlation table will be used. Although some researchers do not agree with this correlation, we believe that it could facilitate the discussion of this research's data with those obtained in the consulted literature.

The human rectus abdominis muscle has a predominance of slow twitch fibers (Type I or SO) $55 \%$ to $58 \%$, Häggmark \& Thorstensson (1979), different from the results found for the rectus abdominis muscle in this research, in which the predominance is of fast twitch fibers $(\mathrm{FG}=\mathrm{IIA}>\mathrm{FOG}=\mathrm{IIB}>\mathrm{SO}=\mathrm{I})$. Nonetheless, in terms of fiber area, the results found for the rectus abdominis muscle of man and those of this research are similar, as the fiber type with greater area is IIB (=FG), Sciote et al. (1994).

Regarding the fiber types that form the rectus abdominis muscle of the rat, literature shows a predominance in frequency of fast twitch fibers, Martin (1979) and Rodrigues et al. (1996), which agrees with the data obtained for the tufted capuchin monkey.

Fig. 4. Rectus abdominis muscle of the tufted capuchin monkey submitted to NADH-Tr reaction.

\section{DISCUSSION}

Few articles on the histochemistry of the rectus abdominis muscle were found in the consulted literature, which makes the comparison of the data found in this
Another quadrupedal that had its rectus abdominis muscle studied was the sheep, Ibebunjo (1993); in which the 3 fiber types (I, IIA, and IIB) were found in equal proportion, different from the data found for the tufted capuchin monkey. In terms of frequency, this research found a predominance for fast twitch fibers in all 4 regions, as observed by Ibejunjo, who analyzed abdominal muscles in sheep. 
The rectus abdominis muscle of the Japanese monkey (Macaca fuscatta) has also been studied, in which 3 fiber types were observed, and fiber frequency showed the following relation: type IIB (FG) > I (SO) > IIA (FOG); Ito (1998). These results are similar to the data found in this study with the tufted capuchin monkey, in which FG fibers showed the highest frequency.

Another aspect that has been approached in studies about muscle fiber types is the observation of the distribution pattern of the fibers, i.e., the frequency and area of the different fiber types in the various portions of a muscle. This is due to the fact that some muscles show regional variations, Acosta \& Roy (1987) and Totland et al. (1988), which researchers call compartimentalization. This is an important aspect because it is acknowledged that when a muscle is formed by more than one compartment it means that it can perform more than one type of activity.

In terms of compartimentalization, Hijikata et al. (1992) observed that in the rectus abdominis muscle of the rat, the percentage of SO fibers increases in a lateral to middle direction, whereas the opposite occurs for the frequency of FG fibers. In the rectus abdominis muscle of the tufted capuchin monkey, it was observed that both frequency and area of FG fibers increase in a proximal to distal direction, but not with a statistically significant difference. As to the other fiber types, no tendency was observed that indicated that there is no compartimentalization in this muscle.

Despite the scarcity of data concerning the rectus abdominis muscle, it can be observed that there is a similarity between the data obtained with primates, Macaca fuscatta and Cebus apella, and a difference with other animals, bipedal or quadrupedal.

One of the few works that relate the morphology of the rectus abdominis muscle to the animal's posture was performed by Curtis (1995), concerning the functional anatomy of the trunk of a primate called Nycticebus coucang. According to this researcher, this animal's locomotion is of slowly climbing trees, characterized by the lateral flexion of the spine, whereas in other quadrupedal primates the flexion and extension movements of the spine are dominant. This author also states that the animal's rectus abdominis muscle presents a long lever arm that may play a significant role in ventroflexion, and that this animal can hang itself upside down, in the posture for feeding; therefore ventroflexion is needed so it can later return to its quadrupedal position.

The numerous descriptions of the locomotion behavior of the Cebus are virtually unanimous, describing it as a very active, fast, agile, running animal, that performs gigantic jumps in an imprudent way; having been considered gymnastics by excellence by Stern.

Freese and Oppenheimer (1981), affirmed that in order to move in land from one place to another, searching for objects or food, the tufted capuchin monkey assumes a bipedal position, and that the seating position is also frequent to these animals. However, this type of quadrupedalism demands for great part of its body weight to be supported by its hindlimbs.

In spite of this information, observations and videos were made of the tufted capuchin monkey, in a free environment as well as in captivity, at the Tufted Capuchin Monkey Procreation Nucleus of UNESP-Araçatuba Campus, confirming the descriptions in terms of its locomotion, made by Freese \& Oppenheimer, and Stern, in addition to the way of hanging itself upside down, as described by Curtis for the Nycticebus coucang when feeding.

Considering that the tufted capuchin monkey uses the movement of dorsiflexion to perform the various aforementioned activities, one could expected that its rectus abdominis muscle would show a histochemical profile with a predominance of fast twitch fibers $(\mathrm{FG}+\mathrm{FOG}=73,11 \%)$, and this was confirmed in this study.

SIMIONATO, L. H.; ANDREO, J. C.; OLIVEIRA, J. A.; BORTOLUCI, C. H. F.; DOS SANTOS, N. B.; MORAES, L. H. R.; RODRIGUES, A. C. \& ANDREO, M.B. Morfometría e histoquímica de las fibras del músculo recto del abdomen, del mono capuchino almohadillado (Cebus apella Linnaeus, 1758). Int. J. Morphol., 24(1):53-60, 2006.

RESUMEN: La proximidad filogenética y las semejanzas de comportamiento, bioquímicos y anatómicos, de los primates con los humanos convierten a estos animales en modelos experimentales más interesantes para las investigaciones biomédicas, que los animales clásicos de laboratorio. Otro aspecto que ha llamado la atención de los investigadores es el movimiento cuádruple diferente que presentan algunos primates. El macado clavo se traslada usando como apoyo el suelo y las ramas de los árboles, presentando posturas variadas en la ejecución de esas tareas. En base a estas informaciones se resolvió estudiar el músculo recto del abdomen del macaco-clavo, con los siguientes objetivos: observar la frecuencia y el área de los tipos de fibras de este músculo; observar posibles diferencias entre ellas y sus regiones media proximal y distal; y su participación en la locomoción de este animal. Para ello, fueron retiradas 4 muestras de 4 regiones del músculo recto del abdomen, de 6 macacos-clavos machos adultos, que fueron sometidos a las reacciones de m-ATPasa (previa incubaciones alcalina y ácida), NADH y HE. Los resultados mostraron: diferencias estadísticamente significativas (p<0,05) tanto en la frecuencia como en el área, entre las fibras del tipo FG y FOG y FG y SO, pero no presentaron diferencias estadísticamente significativas entre las fibras FOG y SO, en todas las regiones estudiadas. Basándome en estos datos, se concluye que el músculo recto del abdomen del macaco-clavo no presenta división de sus fibras, pues los patrones de distribución y tamaño de los diferentes tipo de de fibras son semejantes en las regiones estudiadas con predominio de las fibras de contracción rápida $(\mathrm{FG}+\mathrm{FOG})$ sobre aquellas de contracción lenta $(\mathrm{SO})$, tanto en la frecuencia como en el área, caracterizándolo como un músculo más adaptado para las actividades sutiles que posturales. 


\section{REFERENCES}

Acosta, J. R.; Roy, R. R. Fiber-type composition of skeletal hindlimb muscle of a primate (Cynomolgus monkey). Anat. Rec., 218:136 -41, 1987.

Ariano, M. A.; Armstrong, R. B. \& Edgerton, V. R. Hindlimb muscle fibre populations of five mammals. J. Histochem. Aftochem., 21:51-5, 1973.

Armstrong, R. B.; Saubert, C. W.; Seeherman, H. J. \& Taylor, C. R. Distribuition os fiber types in locomotory muscle of dogs. Am. J.Anat., 163:87-98, 1982.

Behmer, O. A.; Tolosa, E. M. C. \& Freitas Neto, A. G. Manual de técnicas para histologia e patologia. $1^{\mathrm{a}} \mathrm{ed}$. São Paulo, Edart, 1976.

Curtis, D. J. Functional anatomy of the trunk musculature in the Slow Loris (Nyctecebus coucang). Am. J. Phys. Anthropol., 97:367-79, 1995.

Costerbosa, G. L.; Barazzoni, A. M.; Lucchi, M. L. \& Bortolami, R. Fiber sizes and histochemical characteristics of the rectus abdominis muscle of the rabbit under conditions of pregnancy and mechanically induced stress. Anatomical Record, 222:136-44, 1988.

Cooper, R. W. Small species of primates in biomedical research. Laboratory Animal Care, 18(2):267-79, 1968.

Dubowitz, V. \& Brooke, M. Muscle biopsey: a modern approach. $1^{\mathrm{a}}$ ed. London, Sauders, 1973.

Freese, C. H. \& Oppenheimer, J.R. The Capuchin Monkey, Genus Cebus. In: Ecology and behavior of the neotropical primates. Rio de Janeiro. Academia Brasileira de Ciências, 364-65, 1981.

Häggmark, T. \&Thorstensson, A. Fibre types in human abdominal muscle. Acta Phisiol. Scand., 107: 319-25, 1979.

Hijikata, T.; Wakisaka, H. \&Yohro, T. Architectural design, fiber-type composition and innervation of the rat rectus abdominis muscle. Anatomical Record, 234:500-12, 1992.

Ibebunjo, C. Type, diameter and distribuition of fibres in some respiratory and abdominal of fibres in some respiratory and abdominal muscle of the goat. Veterinary Research, 17:171-82, 1993.
Ito, J. Fiber type composition of abdominal muscles in Japanese macaques (Macaca fuscata). Okajimas Folia Anat. Jpn., 74:199-206, 1998.

Johnson, R. A. \& Wichern, D.W. Applied multivasiate statistical analysis. $4^{\mathrm{a}}$ ed. New Jersey, Prentice-Hall, 1998.

Martin, W. D. A Study of the Effect of Pregnancy on Muscle Fibers of the Rectus Abdominis Muscle of the Rat. Anatomical Record, 195:455-62, 1979.

Myrhage, R. Microvascular supple of skeletal muscle fiber. Acta Orthop. Scand., 168 (S), 1977.

Padykula, H. A. \& Herman, E. The specificity of the histochemical method for adenosine triphosphatase. $J$. Hisochem. Cytochm., 3:170-95, 1955.

Pearse, A. E. Histochemistry. Theoretical and applied. $2^{\mathrm{a}}$ ed. Baltimore, Williams and Wilkins, 1968.

Peter, J. B.; Barnard, R. J.; Edgerton, V. R.; Gillespie, C.A. $\&$ Stemdel, K. E. Metabolics profiles of the three fibres types of the skeletal muscle in guinea pigs and rabbits. Biochemistry, 11:2627-33, 1972.

Rodrigues, C. J.; Rodrigues Jr., A. J.; Bohm, G. M. Effects of aging on muscle fibers and collagen content of the diaphagm : A comparison with the rectus abdominis muscle. Gereontology, 42:218-28, 1996.

Sciote, J. J.; Rowlerson, A. M.; Hopper, C. \& Hunt, N. P. Fiber type classification and myosin isoform in the human masseter muscle. J. Neurol Sienc., 126:15-24, 1994.

Stern. J. R. J. T. Functional myology of the hip and thigh of cebid monkeys and its implications for the evolution of erect posture. Basel, Karger, 1971.

Totland, G. K.; Kryvi, H. \& Slind, E. Composition of muscle fiber types and connective tissue in bovine $\mathrm{m}$. semitendinosus and its relation to tenderness. Meat Science, 23:303-15, 1988.

Szabuniewicz, D. V. M.; Schwartz, D. V. S.; Mc Crady, D. V. M. J. D. \& Hussel, L.H. The eletrocardiogram, vectocardiogram and spatiocardiogram in Capuchin Monkey (Cebus apella). Zbl. Vet. Med. A. (18):206 -18, 1971. 
Werneck, L .C. O valor da biopsia muscular em neurologia (Análise de 290 exames a fresco e pela histoquímica). Rev. Brasil. Clin. Terap., 10:2-24, 1981.

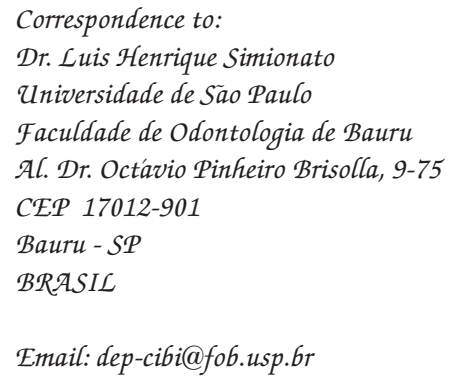

